\title{
A Comparison between Domestic and International Graduate Students on their Work Readiness at a Research University
}

\author{
Jeantyl Norze \\ Louisiana State University \\ Raymond Doe \\ Lamar University \\ Michael F. Burnett \\ Louisiana State University
}

One critical issue in educational programs involves the extent to which graduates are ready to begin

employment at program completion. Additionally, most research universities make deliberate efforts to enroll students from other countries.

An important question regarding the effectiveness of the programs in these universities is whether the international students have comparable preparation and "Work-Readiness" as the domestic students.

This study revealed that on several of the measures associated with "Work-Readiness" international students had lower levels of "Readiness" than domestic students. Also, other differences were found in the groups on issues such as internship experiences and involvement in scholarly activities.

\section{INTRODUCTION}

Higher education provides a person with opportunities to succeed in today's global economy. Colleges and university have a major role in creating a quality workforce. According to O'Banion (2011), colleges and universities hone a student's critical thinking skills in order to solve problems, especially in the workplace. They prepare students for different economic sectors offering various programs, which give them the skills and knowledge they need to stay and progress in the labor market. They are referred as the locus of the generation of knowledge (O'Neil, 1997). However, the extent to which graduates of programs in higher education are actually prepared to enter the workforce or "Work-Ready" when they graduate still remains an issue today. This is even a concern with completers of graduate programs. According to Moxley, Najor-Durack, and Dumbrigue (2001, p.123), "students come into post-secondary and higher education perhaps more with vocation, profession and career in mind than academic matters".

There has never been a time when education is more important than it is today. In fact, the U.S institutions of higher education have been called upon to provide students who graduate the skills they 
need to compete on the global market with their counterparts in other high performing nations (Kirwan, Cantor, Cordova, and Broad, 2005). The quality of a labor-force is decisive for productivity growth (Stadler, 2002). Higher education must offer programs that make a difference for labor market outcomes and "keep pace with changes in the global economy and changes in the innovation process" (QS Asia News Network, 2018, p.3). Institutions of Higher education must assure that their programs are relevant and can help students improve social cohesion, productivity, and growth (QS Asia News Network, 2018). Innovation and productivity improvement are necessary for prosperity to grow globally (Porter and Rivkin, 2012).

This constant growth in higher education in the United States is believed by some to be a major factor in the development of higher education in the U.S. as the best colleges and universities in the world. Looking at World University Rankings 2019, 7 out of the top 10 world best ranking universities are U.S. universities (The Times Higher Education, 2018). The U.S. is viewed as the first choice destination for many international students because of its quality of education, its open labor market, and the hospitality of the American People (Pew Research Center, 2018, OECD, 2016). In fact, the U.S. currently provides higher education to more international students $(n=1.1$ million) than any other country in the world (Zong \& Batalova, 2018).

The motive for internationalization programs in higher education is twofold: financial and academic. Some colleges and universities encounter financial problems and recruit international students to earn profits by charging high fees while others enter the international market because they wish to increase research and knowledge capacity and to increase cultural understanding (Knight, 2006). International students provide research and teaching services for modest compensation — an estimated 12 billion dollars to the U.S. economy, for example (Davis, 2003).

However, some colleges and universities are not fully prepared to "engage and support" these international students so that they receive an equivalent higher education experience to that received by domestic students (Choudaha, 2016). Many international students have felt that their actual experience on U.S. campuses are different from the experience they expected prior to enrollment (Choudaha \& Schulmann, 2014). International students deserve a fair and equal treatment. One way to assess this would be to compare the level of "Work-Readiness" among international students who complete a program with that of domestic students who complete a program in the same university. Completers of graduate level programs were used in this study to maximize the opportunity for both groups of students (international and domestic) to achieve "Work-Readiness."

\section{PURPOSE OF THE STUDY}

The primary purpose of this study was to compare graduate students at a Research University $(\mathrm{RU} / \mathrm{UH})$ in the southern region of the U.S. on their perceived work-readiness and selected academic characteristics by whether or not they were a U.S. citizen.

\section{OBJECTIVES OF THE STUDY}

To achieve the purpose of this study, the objectives were formulated as follows:

1. To describe domestic graduate program completers at a Research University (RU/VH) in Southeastern Region of the United States on selected personal and academic characteristics including:

a. Whether or not the student had an Internship during their program and how many internships they completed;

b. The student's involvement in scholarly activities during their program including articles submitted and published as well as their participation in research conferences;

c. Whether or not the student held an assistantship during their program;

d. The student's perceptions regarding the extent to which they had access to facilities they needed in their educational program; 
e. Their perceptions regarding the extent to which they had access to the faculty expertise they needed; and

f. Their perceived level of Work-Readiness.

2. To describe international graduate program completers at a Research University (RU/VH) in Southeastern Region of the United States on the same group of personal and academic characteristics.

3. To compare the domestic and international students in the study on the set of personal and academic characteristics.

\section{METHODS}

The target population for this study was graduate program completers at Research Universities $(\mathrm{RU} / \mathrm{VH})$ in the Southeastern Region of the United States. A total of 967 graduate program completers who completed the Graduating Student Survey at near the point of their graduation. The instrument used in this study was a computerized Recording Form into which Data from Graduating Student Survey was downloaded.

\section{RESULTS}

The domestic and international students in the study were described separately on the following selected academic variables: whether or not they have an internship, the number of internships, whether or not they held assistantships, participation in conferences, publication status, access to facilities, access to faculty expertise, and work readiness.

\section{Objective 1}

Objective one of the study examined the U.S. domestic students on the following selected academic characteristics:

Internship

Examining the data from the sample of domestic students in the study revealed that over one-third $(34 \%, n=254)$ had completed an internship during their program. Additionally, of the students who had completed an internship, almost half $(46.8 \%, n=116)$ had actually completed 2 or more internships while enrolled in their program. However, more than half $(53.1 \%, n=135)$ of them only completed one internship during the program. The domestic students had on average $1.59(S D=.69)$ internships during their program. The internship experiences of the U.S. domestic students are presented in Table 1.

TABLE 1

\section{FREQUENCY AND PERCENTAGE OF INTERNSHIP EXPERIENCES COMPLETED BY} DOMESTIC GRADUATES AT A RESEARCH UNIVERSITY

\begin{tabular}{|c|c|c|}
\hline Number of Internships & Frequency & Percentage \\
\hline One internship & 135 & 53.1 \\
\hline Two internships & 86 & 35 \\
\hline Three or more internships & 30 & 11.8 \\
\hline Total & 492 & 100 \\
\hline
\end{tabular}

Note. $M=1.59, S D=.69$

\section{Scholarly Activity}

When the involvement of domestic students in scholarly activities was examined, the researcher found that over one-fourth $(26.8 \%, n=69)$ had been successful in getting one or more articles published and about $15 \%(n=40)$ had submitted one or more articles but were unsuccessful in getting them 
published. Additionally, more than half $(54.6 \%, n=141)$ were uncertain regarding whether or not they would publish or indicated that they would not publish in the future. Table 2 summarizes the scholarly activities of the domestic graduate students.

TABLE 2

PUBLICATION STATUS OF THE DOMESTIC GRADUATE STUDENTS DURING THEIR PROGRAM AT A RESEARCH UNIVERSITY

\begin{tabular}{|l|c|c|}
\hline Number of Publications & Frequency & Percentage \\
\hline Publication uncertain & 111 & 43 \\
\hline More than one refereed journal paper published & 42 & 16.3 \\
\hline One refereed journal paper published & 27 & 10.5 \\
\hline Will not publish & 30 & 11.6 \\
\hline One refereed journal paper submitted & 20 & 7.8 \\
\hline More than one refereed journal paper submitted & 20 & 7.8 \\
\hline Book manuscript submitted & 8 & 3.1 \\
\hline Total & 258 & 100 \\
\hline
\end{tabular}

Additionally, the participation of the domestic students in research conference were examined. The findings suggested that less than half $(43.1 \%, n=318)$ of domestic students had attended one or more professional conferences during their program. They attended $.92(S D=1.2)$ professional conferences, on average, during their program. Table 3 summarizes the experiences of the domestic graduate students' attendance at professional conferences during their program.

TABLE 3

PARTICIPATION OF THE DOMESTIC GRADUATE STUDENTS AT A RESEARCH UNIVERSITY IN PROFESSIONAL CONFERENCES

\begin{tabular}{|l|c|c|}
\hline Number of Participation & Frequency & Percentage \\
\hline None & 420 & 56.9 \\
\hline One & 104 & 14.1 \\
\hline Two & 68 & 9.2 \\
\hline Three or more & 146 & 19.8 \\
\hline Total & 738 & 100 \\
\hline
\end{tabular}

Note. $M=.92 ; S D=1.2$

\section{Assistantship}

Examining the sample of the study, the data revealed that almost half $(48.6 \%, n=359)$ of the domestic students held a graduate assistantship while completing their graduate program.

\section{Access to Faculty and Facilities}

The domestic students in the study were also asked to rate their perceived level of access to faculty expertise and to facilities - each as appropriate to graduate education - on a 5 point anchored scale. They rated their level of access to faculty at $3.93(S D=1.09)$ on the 5 point scale while their rating regarding access to facilities was somewhat lower at a rating of $3.77(S D=1.12)$. While not an objective of the study the researchers compared these two ratings using a paired $t$-test and found that among domestic students their perceived access to faculty expertise was significantly higher than their perceived access to facilities. 


\section{Work-Readiness}

The perceived level of work readiness of the domestic students in the study was also examined using a six item scale with a 5 point Likert-type response scale. The scale focuses primarily on the soft skills associated with being work-ready. The scale was found to have a high level of internal consistency as measured by Cronbach's Alpha reliability estimate $($ Alpha $=.91)$. The scale was also factor analyzed and yielded a single factor with loadings ranging from .87 to .80 . The mean score of the perceived level of work-readiness of the domestic students was $3.93(S D=.81)$.

\section{Objective 2}

Objective two of the study examined the international students on the following selected academic characteristics:

\section{Internship}

Examining the data from the sample of international students in the study, it is found that less than one-fourth $(22.6 \%, n=49)$ as compared to more than one-third $(34 \%, n=254)$ among the domestic students had completed an internship during their program. Additionally, of the students who had completed an internship, just over one third $(34.7 \%, n=17)$ as compared to almost half among the domestic students $(46.8 \%, n=116)$ had actually completed 2 or more internships while enrolled in their program. However, almost two third $(65.3 \%, n=32)$ of the international students who responded had only one internship during their graduate program. Table 4 summarizes the number of internship experiences of international students during their graduate program.

TABLE 4

\section{FREQUENCY AND PERCENTAGE OF INTERNSHIP EXPERIENCES COMPLETED BY INTERNATIONAL STUDENTS DURING THEIR GRADUATE PROGRAM AT A RESEARCH UNIVERSITY}

\begin{tabular}{|l|c|c|}
\hline Number of Internships & Frequency & Percentage \\
\hline One internship & 32 & 65.3 \\
\hline Two internships & 14 & 28.6 \\
\hline Three or more internships & 3 & 6.1 \\
\hline Total & 49 & 100 \\
\hline
\end{tabular}

\section{Scholarly Activity}

When the scholarly activities of the international students in the study, almost half $(46 \%, n=62)$ of the international graduate students has been successful in getting one or more journal articles published and about $11.8 \%(n=16)$ had submitted one or more articles but were unsuccessful in getting them published. Additionally, less than half $(40 \%, n=54)$ were uncertain regarding whether or not they would publish or indicated that would not publish in the future. Table 5 provides a brief summary of the publication status of the international students who participated in the study. 
TABLE 5

PUBLICATION STATUS OF INTERNATIONAL STUDENTS DURING THEIR GRADUATE PROGRAM AT A RESEARCH UNIVERSITY

\begin{tabular}{|l|l|l|}
\hline Number of Publications & Frequency & Percentage \\
\hline Publication uncertain & 44 & 32.6 \\
\hline More than one refereed journal paper published & 41 & 30.4 \\
\hline One refereed journal paper published & 21 & 15.6 \\
\hline One refereed journal paper submitted & 11 & 8.1 \\
\hline Will not publish & 10 & 7.4 \\
\hline More than one refereed journal paper submitted & 5 & 3.7 \\
\hline Book manuscript submitted & 3 & 2.2 \\
\hline Total & 135 & 100 \\
\hline
\end{tabular}

Also, the participation of the international students in professional conferences during their graduate program was examined. The data suggested that more than half $(52.5 \%, n=115)$ had attended one or more professional conferences during their program. They attended $1.15(S D=1.26)$ professional conference, on average, during their program. The participation of international students in professional conference during their program is presented in Table 6.

TABLE 6

PARTICIPATION OF THE INTERNATIONAL STUDENTS IN PROFESSIONAL CONFERENCE DURING THEIR GRADUATE PROGRAM

\begin{tabular}{|l|l|l|}
\hline Number of Participation & Frequency & Percentage \\
\hline None & 104 & 47.5 \\
\hline One & 31 & 14.2 \\
\hline Two & 29 & 13.2 \\
\hline Three or more & 55 & 25.1 \\
\hline Total & 219 & 100 \\
\hline
\end{tabular}

\section{Assistantship}

The international students were also asked about whether or not they had held an assistantship during their program. The data suggested that most $(83.6 \%, n=183)$ international students in the study held a graduate assistantship (as compared to less than half $(48 \%, n=359)$ of the domestic students) while completing their program.

\section{Access to Faculty and Facilities}

The international students in the study were also asked to rate their perceived level of access to faculty expertise and facilities - each as appropriate to graduate education - on the 5 point anchored scale; they rated their level of access to faculty expertise at $3.90(S D=1.16)$ on the 5 point scale while their rating regarding access to facilities was somewhat higher a rating of $3.98(S D=1.14)$. Again, the researchers compared these two ratings using a paired $t$-test even though they were not an objective of the study. The findings suggested that these two ratings were not significantly different.

\section{Work-Readiness}

The perceived level of work-readiness of the international students in the study was measured using the same six item scale with a 5 point Likert-type response scale. The mean score of the overall workreadiness for the international students in the study was $3.76(S D=.84)$. 


\section{Objective 3}

Objective three of the study compared the domestic students and the international students at a Research University on the variables being investigated.

\section{Internship}

The first of these variables examined was whether or not the student (domestic and international) completed an internship during their program. The significant chi-square value $(p=.001)$ indicated that a higher proportion $(34 \%, n=254)$ of domestic students completed an internship in their program than international students $(22.6 \%, n=49)$ did (see Table 7$)$.

TABLE 7

COMPARISON BETWEEN DOMESTIC AND INTERNATIONAL STUDENTS ON THEIR INTERNSHIP EXPERIENCE DURING THEIR GRADUATE PROGRAM

\begin{tabular}{|c|c|c|}
\hline \multirow{2}{*}{$\begin{array}{c}\text { Whether or Not Had } \\
\text { Internship }\end{array}$} & \multicolumn{2}{|c|}{ Whether or Not a U.S. Student } \\
\cline { 2 - 3 } & $\underline{\mathrm{n}}$ & No \\
& $\frac{\mathrm{n}}{\%}$ & $\mathbf{0}$ \\
\hline \multirow{2}{*}{ Yes } & 254 & 49 \\
& 34 & 22.6 \\
\hline \multirow{2}{*}{ No } & 492 & 168 \\
& 66 & 77.4 \\
\hline \multirow{2}{*}{ Total } & 746 & 217 \\
& 100.0 & 100.0 \\
\hline
\end{tabular}

Note. $\mathbf{X}_{(\mathbf{1})}=10.25, p=.001$

\section{Assistantship}

When the domestic students were compared to the international students on whether or not they held an assistantship while enrolled in their program. The significant chi-square value $(p<.001)$ indicated that a higher proportion $(83.6 \%, n=183)$ of international students were found to have been on assistantship during their graduate program than the domestic students $(48.6 \%, \mathrm{n}=359)$ (see Table 8$)$.

TABLE 8

COMPARISON BETWEEN DOMESTIC AND INTERNATIONAL STUDENTS ON THEIR ASSISTANTSHIP HELD DURING THEIR GRADUATE PROGRAM

\begin{tabular}{|c|c|c|}
\hline \multirow{2}{*}{$\begin{array}{c}\text { Whether or Not Had } \\
\text { Assistantship }\end{array}$} & \multicolumn{2}{|c|}{ Whether or Not a U.S. Student } \\
\cline { 2 - 3 } & Yes & No \\
& $\frac{\mathbf{n}}{\mathbf{n}}$ \\
\hline \multirow{2}{*}{ Yes } & 359 & 183 \\
\hline \multirow{2}{*}{ No } & 48.6 & 83.6 \\
\hline \multirow{2}{*}{ Total } & 379 & 36 \\
& 51.4 & 16.4 \\
\hline
\end{tabular}

Note. $\chi_{(\mathbf{1})}^{2}=83.84, p=<.001$ 


\section{Scholarly Activities}

When the groups of students were compared on their involvement in scholarly activities, a significant chi-square indicated that these variables (publication status/domestic/international students) were not independent $\left(\chi_{(6)}^{2}=16.754, p=.010\right)$ (see Table 9). A higher proportion $(46 \%, n=62)$ of international students were found to have published one or more refereed journal articles while a higher portion $(54.6 \%, n=141)$ of domestic students were found to have indicated that they either were uncertain about their involvement in publishing or would definitely not publish.

TABLE 9

COMPARISON BETWEEN DOMESTIC AND INTERNATIONAL STUDENTS ON THEIR PUBLICATION STATUS DURING THEIR GRADUATE PROGRAM

\begin{tabular}{|l|c|c|}
\hline \multirow{2}{*}{ Publication Status } & \multicolumn{2}{c|}{ Whether or Not a U.S. Student } \\
\cline { 2 - 3 } & Yes & No \\
& $\frac{\mathrm{n}}{\%}$ & $\frac{\mathrm{n}}{\%}$ \\
\hline \multirow{2}{*}{ One refereed journal paper published } & 27 & 21 \\
& 10.5 & 15.6 \\
\hline \multirow{2}{*}{ More than one refereed journal paper published } & 42 & 41 \\
& 16.3 & 30.4 \\
\hline \multirow{2}{*}{ One refereed journal paper submitted } & 20 & 11 \\
& 7.8 & 8.1 \\
\hline \multirow{2}{*}{ More than one refereed journal paper submitted } & 20 & 5 \\
& 7.8 & 3.7 \\
\hline \multirow{2}{*}{ Book manuscript submitted } & 8 & 2.2 \\
\hline \multirow{2}{*}{ Publication uncertain } & 3.1 & 44 \\
\hline \multirow{2}{*}{ Will not publish } & 111 & 32.6 \\
\hline \multirow{2}{*}{ Total } & 43 & 10 \\
& 30 & 135 \\
\hline
\end{tabular}

Note. $\chi_{(6)}^{2}=16.754, p=.010$

The domestic students were also compared to international students on their involvement or participation in professional conferences during their graduate program. The results suggested that theses variables were independent $\left(\chi_{(3)}^{2}=7.727, p=.052\right)$. The results are presented in Table 10 . 
TABLE 10

COMPARISON BETWEEN DOMESTIC AND INTERNATIONAL STUDENTS ON THEIR PARTICIPATION IN A PROFESSIONAL CONFERENCE DURING THEIR GRADUATE PROGRAM AT A RESEARCH UNIVERSITY

\begin{tabular}{|l|c|c|}
\hline \multirow{2}{*}{$\begin{array}{c}\text { Participation in } \\
\text { conferences }\end{array}$} & \multicolumn{2}{|c|}{ Whether or Not a U.S. Student } \\
\cline { 2 - 3 } & $\underline{\mid}$ & No \\
& $\frac{\mathrm{n}}{\mathrm{n}}$ \\
\hline \multirow{2}{*}{ None } & 420 & 104 \\
& 56.9 & 47.5 \\
\hline \multirow{2}{*}{ One } & 104 & 31 \\
& 14.1 & 14.2 \\
\hline \multirow{2}{*}{ Two } & 68 & 29 \\
& 9.2 & 13.2 \\
\hline \multirow{2}{*}{ Three or more } & 146 & 55 \\
& 19.8 & 25.1 \\
\hline \multirow{2}{*}{ Total } & 738 & 219 \\
& 100.0 & 100.0 \\
\hline
\end{tabular}

Note. $\chi_{(3)}^{2}=7.727, p=.052$

Access to Faculty expertise and Facilities

Another variable investigated was whether or not a significant difference existed between the perceived level of access to faculty expertise and facilities of the domestic and international students. When examining the data, no significant differences were found in the students' perceived access to faculty expertise. However, the international students perceived that they had more access to facilities $(M$ $=3.98, \mathrm{SD}=1.14)$ than the domestic students $(M=3.77, S D=1.12)$ for $t(955)=-2.38, p=.017$. The results are presented in Table 11.

TABLE 11

COMPARISON BETWEEN DOMESTIC STUDENTS AND INTERNATIONAL STUDENTS ON THEIR PERCEIVED LEVEL OF ACCESS TO FACULTY EXPERTISE AND FACILITIES

\begin{tabular}{|c|c|c|c|c|}
\hline Variable & $\begin{array}{c}\text { U.S. Domestic } \\
\text { Students } \\
\underline{\underline{\mathbf{n}}} \\
\underline{\underline{\mathbf{m}}}\end{array}$ & $\begin{array}{c}\text { International } \\
\text { Students } \\
\underline{\underline{\mathbf{n}}} \\
\underline{\underline{\mathbf{S D}}}\end{array}$ & $\underline{\mathbf{t}}$ & $\underline{\text { Sig. }}$ \\
\hline $\begin{array}{l}\text { Access to facilities was } \\
\text { appropriate for graduate } \\
\text { education }\end{array}$ & $\begin{array}{l}738 \\
3.77 \\
1.12 \\
\end{array}$ & $\begin{array}{l}219 \\
3.98 \\
1.14\end{array}$ & -2.38 & .017 \\
\hline $\begin{array}{l}\text { Access to faculty expertise } \\
\text { was appropriate for } \\
\text { graduate education }\end{array}$ & $\begin{array}{l}738 \\
3.93 \\
1.09\end{array}$ & $\begin{array}{l}219 \\
3.90 \\
1.16\end{array}$ & .34 & .74 \\
\hline
\end{tabular}

Work Readiness

The work-readiness scores for the domestic students were also compared with those of the international students using an independent sample $t$-test (see Table 12). The domestic students were 
found to have a significantly higher perceived level of Work-Readiness $(M=3.93, S D=.81)$ than the international students in the study $(M=3.76, S D=.84)(t(963)=2.76, p=.0006)$.

Since there were differences in the overall Work-Readiness, each individual item included in the Work-Readiness scale were examined in attempt to more clearly understand the nature of the difference. Three of the six items were found to be significantly different by whether the student was domestic or international. These items included "building meaningful relationships", "connecting to other knowledge, ideas, and experience", and "relating knowledge to daily life".

The item "building meaningful relationships" had the greatest degree of difference $(t(963)=3.141, p$ $=.002$ ). The item "connecting to other knowledge, ideas, and experience" came second in terms of degree of difference $(t(963)=2.953, p=.003)$. The item "relating knowledge to daily life" came last in terms of degree of difference $(t(963)=2.951, p=.003)$. The results are presented in Table 12.

TABLE 12

COMPARISON BETWEEN DOMESTIC STUDENTS AND INTERNATIONAL STUDENTS ON THEIR PERCEIVED LEVEL OF WORK READINESS

\begin{tabular}{|c|c|c|c|c|}
\hline Variable & $\begin{array}{l}\text { U.S. Domestic } \\
\text { Students } \\
\underline{\underline{\mathbf{m}}} \\
\underline{\mathbf{S D}}\end{array}$ & $\begin{array}{c}\text { International } \\
\text { Students } \\
\frac{\mathbf{n}}{\underline{\mathbf{m}}} \\
\underline{\mathbf{S D}}\end{array}$ & $\underline{\mathbf{t}}$ & Sig. \\
\hline $\begin{array}{l}\text { Building meaningful } \\
\text { relationships }\end{array}$ & $\begin{array}{c}\overline{746} \\
3.942 \\
1.024\end{array}$ & $\begin{array}{c}219 \\
3.694 \\
1.046\end{array}$ & 3.141 & .002 \\
\hline $\begin{array}{l}\text { Connecting to other } \\
\text { knowledge, ideas, } \\
\text { experiences }\end{array}$ & $\begin{array}{c}746 \\
3.961 \\
.914 \\
\end{array}$ & $\begin{array}{c}219 \\
3.753 \\
.920 \\
\end{array}$ & 2.953 & .003 \\
\hline $\begin{array}{l}\text { Relating knowledge to } \\
\text { daily life }\end{array}$ & $\begin{array}{c}746 \\
3.822 \\
.969\end{array}$ & $\begin{array}{c}219 \\
3.603 \\
.954\end{array}$ & 2.951 & .003 \\
\hline Work Readiness & $\begin{array}{c}746 \\
3.929 \\
.811\end{array}$ & $\begin{array}{c}219 \\
3.756 \\
.837\end{array}$ & 2.767 & .006 \\
\hline $\begin{array}{l}\text { Collaboration with } \\
\text { others }\end{array}$ & $\begin{array}{c}746 \\
3.972 \\
.975\end{array}$ & $\begin{array}{c}219 \\
3.767 \\
.931\end{array}$ & 2.759 & .006 \\
\hline $\begin{array}{l}\text { Ability to work with } \\
\text { others }\end{array}$ & $\begin{array}{c}746 \\
4.021 \\
.958\end{array}$ & $\begin{array}{c}219 \\
3.922 \\
.928\end{array}$ & 1.355 & .176 \\
\hline $\begin{array}{l}\text { Determining future } \\
\text { career }\end{array}$ & $\begin{array}{c}746 \\
3.858 \\
1.069 \\
\end{array}$ & $\begin{array}{c}219 \\
3.795 \\
1.057 \\
\end{array}$ & .774 & .439 \\
\hline
\end{tabular}

\section{DISCUSSIONS AND IMPLICATIONS}

Overall, the international students in the study had a lower level of work readiness than the domestic students. Also, the descriptive results showed that the domestic students accounted for more than three times the size of non-US citizens. Even though the literature on work readiness looking at citizenship 
influences is scarce, this result in the broader context tends to be consistent with self-efficacy and crosscultural reviews. Klassen (2004), for instance, reviewed 20 studies and found that self-efficacy beliefs are lower for non-western cultural groups. Whereas this study's variable 'Whether or not US citizen' cannot be equated with western and non-western dichotomy, or the individualistic and collectivism divide, Klassen (2004) indicated that self-efficacy beliefs do not always predict performance of all cultural groups, although it is a strong predictor of performance in western cultures. That is to say that perceiving oneself as ready for the world of work does not automatically translate to performance on the job across all cultures. In addition, however, when training is tailored to individual's self-worth, both efficacy beliefs and performance tend to increase (Klassen, 2004).

The international students in the study also had fewer internships than the domestic students. The finding may indicate that international students have had a hard time obtaining internships in the U.S. because there are a limited number of U.S organizations that are willing to work with them. According to Gardner (2013), only one-third of 1900 employers responded favorably when they were asked whether they would consider assisting international students. Small organizations were also reported to be more favorable to provide internships to international students than large organizations. Having an internship during a graduate program that mandates some form of work usually outside the university exposes the graduate students to the real world of work. This type of learning enables the student to develop teamwork, communication, research, critical analysis and solving of real world problems (Duch et al., 2001). It also offers graduate students the opportunity to connect classroom learning experiences to the real world of work (Boud, 2010).

The findings suggest that the international students, however, had higher number of articles published than their counterpart domestic students. International students seem to put greater emphasis or importance on publications than did the domestic students. This may be explained by the fact that a higher proportion of international students held assistantships than the domestic students during their graduate program. Having an assistantship might increase the interaction between faculty and graduate students. However, when examining the data, no significant differences were found in the students' perceived access to faculty expertise which should logically be considered a positive outcome. According to Weidman and Stein (2003), the participation of students in scholarly activities are associated with social interaction between faculty and students. As such, graduate assistants contribute to the U.S. economy both directly through scholarly involvement and indirectly by teaching and training future professionals.

\section{Future Research}

Since international students were reported to have a lower level of perceived work-readiness than their domestic counterparts. The researchers recommend additional research to determine the specific impact of experiences such as internships and assistantships on perceived work-readiness. Additional research is also recommended to explore this finding in-depth in future studies to examine, perhaps qualitatively, what perception of work readiness means to different cultural groups. Departments and graduate faculty specifically should seek to provide equitable experience for all graduate degree completers including domestic and international students.

\section{REFERENCES}

Boud, D. (2010). Assessment 2020. Seven propositions for assessment reform in higher education [online]. Sydney, NSW: Australian Learning and Teaching Council. Retrieved from: http://www.altc.edu.au/resource-student-assessment-learning-and-after-courses-uts2010

Choudaha, R., \& Schulmann, P. (2014). Bridging the gap: Recruitment and retention to improve international student experiences. NAFSA: Association of International Educators.

Choudaha, R. (2016). Campus Readiness for Supporting International Student Success. Journal of International Students, 6(3). ISSN: 2166-3750.

Davis, T. M. (2003). Atlas of student mobility. New York: Institute of International Education. 
Duch, B. J., Groh, S. E., \& Allen, D. E., eds. (2001). The power of problem-based learning: a practical 'how to 'for teaching undergraduate courses in any discipline. Sterling, VA: Stylus.

Gardner, P. (2013). Employers' Thoughts on International Students for Internships and Fulltime Positions. CERI Research Brief, 1. Michigan State University.

Kirwan, W. E., Cantor, N., Cordova, F., \& Broad, M. (2005). Creating flexibility in tenure-track faculty careers. American Council on Education, spring, 34-38.

Klassen, R. M. (2004). Optimism and realism: A review of self-efficacy from a cross-cultural perspective. Journal of Psychology 39(3), 205-230.

Knight, J. (2006). Internationalization of higher education: New directions, new challenges. The 2005 IAU global survey report. Paris: International Association of Universities.

Moxley, D., Najor-Durack, A., \& Dumbrigue, C. (2001). Keeping Students in Higher Education. London: Kogan Page.

O'Banion, T. (2011). Focus on learning: The core mission of higher education. In Terry O'Banion \& Cynthia Wilson (eds.) Focus on Learning: A Learning College Reader (pp 3-8). League for Innovation in the Community College: Phoenix, AZ.

O’Neil, H. (1997). Workforce Readiness: Competencies and Assessment.

OECD (2016). Education at a glance. Paris: OECD Publishing. http://dx.doi.org/10.187/eag-2016-en.

Pew Research Center (2018). The public, the political system and American democracy. Retrieved from http://www.people-press.org/2018/04/26/the-public-the-political-system-and-americandemocracy/.

Porter, M. E., \& Rivkin, J. W. (2012). The Looming Challenge to U.S. Competitiveness. Harvard Business Review. Retrieved from https?hbr.org/2012/03/the-looming-challenge-to-uscompetitiveness.

QS Asia New Network (2018). Importance of Higher Education for Today's Economy. Retrieved from https://qswownews.com/importance-of-higher -education/.

Stadler, M. (2002). Innovation and growth: The role of labor-force Qualification. Tübinger Diskussionsbeiträge, 255, Wirtschaftswiss. Fak. der Eberhard-Karls-Univ., Wirtschaftswiss. Seminar, Tübingen, http://nbn-resolving.de/urn:nbn:de:bsz:21-opus-18810

The Times Higher Education (2018). World University Rankings 2018. Retrieved from https://www.timeshighereducation.com/world-university-rankings/2018/worldranking\#!/page/0/length/25/sort_by/rank/sort_order/asc/cols/stats.

Weidman J. C., \& Stein, E. L. (2013). Socialization of Doctoral Students to Academic Norms. Research in Higher Education, 44(6).

Zong, J., \& Batalova, J. (2018). International Students in the United States. The Online Journal of the Migration Policy Institute. Retrieved from https://www.migrationpolicy.org/article/internationalstudents-united-states. 